\title{
COMPARATIVE AND COMPETITIVES ADVANTAGES: PERSPECTIVE OF RURAL TOURISM (STUDY ON TOURISM IN THE PROVINCE OF BALI INDONESIA)
}

\author{
I Made WARDANA* \\ Udayana University, Department of Management, Faculty of Economics and Business, Bali, Indonesia, e-mail: wardana @unud.ac.id \\ I Putu Gde SUKAATMADJA \\ Udayana University, Department of Management, Faculty of Economics and Business, Bali, Indonesia, e-mail: sukaatmadja@ yahoo.co.id \\ Ni Nyoman Kerti YASA \\ Udayana University, Department of Management, Faculty of Economics and Business, Bali, Indonesia, e-mail: manraikerti@yahoo.co.id \\ Made SETINI \\ Udayana University, Department of Management, Faculty of Economics and Business, Bali, Indonesia, e-mail: Gitan4nd4@gmail.com
}

\begin{abstract}
Citation: Wardana, I.M., Sukaatmadja, I.P.G., Yasa, N.N.K., \& Setini, M. (2020). COMPARATIVE AND COMPETITIVES ADVANTAGES: PERSPECTIVE OF RURAL TOURISM (STUDY ON TOURISM IN THE PROVINCE OF BALI INDONESIA). GeoJournal of Tourism and Geosites, 33(4spl), 1493-1500. https://doi.org/10.30892/gtg.334spl07-598
\end{abstract}

\begin{abstract}
Rural tourism is an interpretation of the development of culture-based and environmentally sustainable tourism and involves various stakeholders including local communities. Data were analyzed using the SEM-PLS, sample Research respondents numbered 192 including farmers, tourism industry players, village leaders, NGOs, academics and the government. The findings of this study are that community involvement in sustainable rural tourism has a positive and significant impact on efforts to build a comparative advantage of village tourism. Meanwhile, community involvement does not have a significant effect on efforts to build competitive advantage. Government involvement in sustainable rural tourism has no significant effect on efforts to build a comparative advantage of village tourism. Meanwhile, government involvement has a positive and significant effect on efforts to build a competitive advantage in rural tourism. The involvement of the private sector and non-governmental organizations has a positive and significant effect on sustainable rural tourism and the competitive advantage of rural tourism. Meanwhile, the involvement of the private sector and non-governmental organizations has no significant effect on the comparative advantage of rural tourism. The role of the Government involvement, the private sector must be linked with the non-governmental organizations self-help so that it has a positive impact towards the development of sustainable rural tourism.
\end{abstract}

Key words: sustainable rural tourism, comparative advantage, competitive advantage.

\section{INTRODUCTION}

The growth of tourism in recent years confirms that this sector is one of the most powerful drivers of economic growth and development at present. The pattern of mass tourism has been largely abandoned for the pattern of intention tourism or quality tourism.

Rural tourism is an interpretation of the development of tourism that is based on culture and environment sustainable and involves various stakeholders including the local community, and the development of rural tourism has indeed taken place since World War II. Factors that affect the development of rural tourism can be bilateral, namely in terms of tourism (demand) and the organizer (supply) (Afonso, 2020; Lee and Jan, 2019). The development of rural tourism is in line with the Indonesian government's development policies that prioritize rural development by rolling out significant village funds. Rural development aims to improving the welfare of the community and overcoming the problem of unemployment through employment opening by encouraging the growth of economic activity in the countryside (Xiong et al., 2020). The development of rural tourism will not be separated from the support of other stakeholders such as the role of government, the tourism industry and the role of non-governmental organizations moving rural tourism into economic and social activities to improve the welfare of the wider community (Sook et al., 2014).

Jaafar et al. (2020) suggested that the development of rural tourism must be community based and involve various community resources. Communities must play an integral role in tourism development and propose an approach that emphasizes the need for community control and management over the development of local tourism. Previous researchers suggested that local people are people who are familiar with tourists through their local cultural activities. Therefore, their involvement and support is very important for the success and development of rural tourism (Shibin et al., 2020). However, many tourism authorities and stakeholders ignore this important fact and oppose the idea of local community involvement in the development of rural tourism (Ma et al., 2020; Fang, 2020). In addition, there is a lack of participation among local people in rural tourism due to paternalism, racism, clientelism, lack of experti se, and lack of financial resources that hinder the process of community participation (Dogra and Gupta, 2012; Ma et al., 2020). Therefore, it is very important to involve local communities and their support is related to the development of sustainable rural tourism.

Furthermore according to Kubickova, M. (2016), in developing countries, the private sector cannot get compensated to produce additional benefits for tourism. However, the extra benefits will have an impact on competitiveness. This is where the externality argument is used to justify government involvement. Croes (2014); Carvache-Franco et al. (2019) has pointed out that the provision of public goods is crucial for tourism competitiveness, making it a convincing argument for government intervention. In some countries the role of nongovernmental organizations (NGOs), in improving the welfare of the community, especially rural communities is very high. There are several roles that can be played by NGOs in tourism development, such as: as a facilitator, as an initiator of community-based tourism development, as a trainer and provider of information sources, as a collaborative partner of the area manager, as a supervisor of government performance.

\footnotetext{
${ }^{*}$ Corresponding author
} 
In the development of rural tourism comparative advantage becomes very important because excellence in the context of village potential is something unique (not man-made) owned by the countryside such as natural beauty, culture and customs. Regarding comparative advantage in service products is a relatively new concept. In Bali each village has the potential for excellence, it's just that it needs to be explored and empowered such as the natural beauty of culture, customs and local wisdom to be organized and offered in rural tourism activities. In addition to comparative advantage that relies on unique resources, competitive advantage is the concern of every company in order to compete and dominate the market. Competitiveness reflects the strength of the company in the market, by controlling more of the market share than other companies. In the tourism sector competitiveness is a very important strategy. The concept of competitiveness has been adapted from economic theory and applied to companies and the model proposed by Porter (1980; 1990) has been widely discussed in various industries. The main theme of this model is that companies must find better ways to compete by continuously improving products and processes to create competitive advantage. Moreover, competitiveness has been seen as an effort to produce more quality goods and services that are marketed to consumers.

The aim of the research is to investigate the role of primary or key stakeholders namely local communities, government, private sector and NGOs in the development of sustainable rural tourism, increasing comparative advantage and competitive advantage.

\section{LITERATURE REVIEW}

\section{Rural Tourism}

According to Fang (2020), rural tourism is defined as the type of tourism located in rural areas, rural tourism has a different scale and character functions. If someone wants a vacation in rural tourism, the following characteristics must be contained in the holiday (1) located in a rural area, (2) based on rural tourism features, (3) owning buildings and settlements on a small scale, (4) relating to local residents, (5) based on location in villages and small towns, (6) illustrates an economic, environmental and historical pattern.

Recent studies have found that rural tourism can improve the identity of an entire country because it is closely related to ways of life, local production, cultural celebrations and heritage (Ursache, 2015). During their visit to the destination, tourists have the opportunity to enjoy the facilities and appeal of rural areas and of course get a positive experience that will affect the likelihood of the ir return visit (Komppula, 2014). The concept of rural tourism with its unique, distinctive and environmentally friendly products can be a new solution for the development of tourism in the world (Giampiccoli et al., 2020). In response to the shift in tourist interest, Indonesia's tourism options are growing in the form of village's tourism in various provinces in Indonesia. The development of a village tourism is not only beneficial for the emergence of alternative tourism to meet shifting tourist interests, but can also be used as a solution to the problem of poverty, cultural preservation and environmental preservation. The development of sustainable rural tourism has been defined as tourism that focuses on appropriate policies and strategies that can guarantee the benefits received and limit the negative impacts of rural tourism on rural communities (Ertuna and Kirbas, 2012). There are four dimensions in the development of sustainable rural tourism, namely social, cultural, economic, and environmental sustainability (Prevolšek et al., 2020).

\section{Stakeholders in Rural Tourism}

A review of relevant tourism literature reveals the importance of understanding perceptions of stakeholders in the development of sustainable tourism in each tourism destination or community. Stakeholders are defined as individuals or groups who can influ ence or be influenced by the achievement of organizational goals. There is no doubt that rural tourism stakeholders have an important role to play in this success. Cooperation and support between stakeholders is crucial for the sustainability of rural tourism. This will be an effective strategy for the landscape and rural sector. According to Ezeuduji (2015), stakeholders in a destination can manage rural tourism development. Stakeholders in detail are local communities, national and regional governments, national environmental agencies, tourism authorities, non-profit organizations, and tourism industry players.

\section{Local Community Involvement}

Local communities must play an integral role in tourism development where local communities can exercise control over tourism activities and management of local tourism development (Wardana, 2018). Local communities must be included in rural tourism strategies, because rural tourism cannot be successful without community support (Falak et al., 2014). Some researchers have stated that many studies are more concerned with tourist satisfaction and less attention is paid to the role of local communities in rural tourism (Fang, 2020; Falak et al., 2014). However, some researchers have pointed out the need for local education and to give more attention to local resources in rural areas (Fang, 2020). Communication between the host and guest is a component of the rural experience. Local residents help tourists to discover rural areas and enjoy the experience. They also shared knowledge about the history, culture and nature of the area. Local people act as cultural intermediaries, reducing the distance between tourists and their destinations. In other words, local residents allow tourists to further explore their experiences (Kastenholz et al., 2012).

Success in building tourist destinations is very much influenced by the support and active role of the community, so that tou rism development needs to involve the community. On the other hand, because tourism is a business activity, consideration s for developing highly competitive destinations must be taken so that the destination has a comparative and competitive advantage, while a strategic planning approach is adopted to ensure the above factors can be achieved. From the references above there is no doubt that community involvement will correlate with efforts to develop sustainable Rural Tourism because this type of tourism offers old beauty, environmental sustainability, culture, customs and historical relics. Community-based Rural Tourism Development will automatically strengthen rural resources as a component of the comparative and competitive advantage of rural tourism destinations.

\section{Government Involvement}

The government has a vital role to play in supporting business and rural tourism destinations. The government must determine the needs of stakeholders for rural tourism. According to Lee and Jan (2019), the government facilitates the development of rural tourism businesses. The Taiwanese government manages agricultural projects to encourage farmers to enter Taiwan's rural tourism. Kubickova (2016) found local governments and institutions to have political authority and power for effective management of sustainable tourism development. The term management is related to two basic concepts: the concept of governance and the concept of administrations.

The concept of governance shows the behavior of authorities and the process of political decision making in formal institutions and government. The term governance refers to the methods and procedures used by government and non-government organizations together, working to realize planned objectives (Sandri et al., 2020). Local governments are generally considered the most suitable for coordinating tourism development at the local level and for encouraging sustainable tourism development programs (Kubickova, 2016). For this reason, local governments must develop management and communication processes that are appropriate to interest groups (Birkić et al., 2014). 


\section{Private and NGOs. Involvement}

A key determinant in the contribution of NGOs towards development is the relationship between them and the state. NGOs may run parallel activities, play oppositional roles, or they may represent weaker members of society, organizing them to become more influential in decision making and resource allocation (Clark, 1999). NGOs have distinctive roles and responsibilities in the development process, sometimes challenging and sometimes complementing the role of the state (Attack, 1999). The role of NGOs, in improving the welfare of the community, especially rural communities is very high. According to Giampiccoli et al. (2020); Wardana et al. (2020) there are several roles that NGOs can play in tourism development, such as (1) As a facilitator or liaison between tourism stakeholders, for example: between the tourism industry and local communities, between managers of protected areas and local communities, and between government and local communities. (2) As the initiator of community-based ecotourism development in order to be able to expand objectives and obtain greater conservation impacts by optimizing the role and cooperation with other stakeholders. (3) As a trainer and provider of relevant information sources related to tourism issues. (4) As partners in the management of protected areas to implement the objectives of tourism development such as; environmental education programs and natural resource utilization programs. (5) As a supervisor of government performance, especially departments that handle protected areas to ensure the programs are running properly.

\section{Comparative Advantage}

There is little research on comparative advantage in developing countries, especially in service sector. Findings and recommendations policy can be used by developing countries to increase the competitiveness of their service sector (Liu and Xie, 2020). Comparative advantage is a concept developed by David Ricardo to explain the efficiency of resource allocation in a country in an open economic system (Falciola et al., 2020). The steps to realize comparative advantage towards competitive advantage are (1) increasing the application of technology so as to increase efficiency and productivity. (2) guarantee marketing and price certainty. (3) forming bonds that need each other (Othman et al., 2020).

\section{Competitive advantage}

Measuring the relative success of tourism destinations is competitiveness (Fernández et al., 2020; Croes, 2014). Defining the competitiveness of tourism destinations according to experts is difficult because the competitiveness of destinations is very complex, influenced by various factors, namely social, economic, cultural and political factors (Yasa et al., 2020).) The competitiveness of a tourism destination is if the destination is able to increase the volume of visitor arrivals (Dogru et al., 2020.

A more detailed description of the competitiveness of tourism destinations is (1) increased tourist expenditure, (2) has an attraction, (3) can provide a good experience to tourists, (4) environmental preservation, (5) improve the welfare of local communities. However, the most accepted definition of tourism competitiveness comes from general economic theory which refers to market mechanisms and components of the tourism industry that can successfully maintain the attractiveness of tourism destinations (Ferreira et al., 2020). Thus rural tourism is at least able to offer experiences to tourists relating to local resources owned by the village such as traditional buildings with local cultural architecture, untouched nature including flora and fauna, efficient transportation of tourists and recreational facilities.

\section{RESEARCH CONCEPTUAL FRAMEWORK}

Sook et al. (2014); Xiong et al. (2020) in their research in Kuching proved that there are three dimensions of community involvement: community participation in decision making, empowerment, and knowledge about tourism have a significant effect on the development of sustainable rural tourism. However the dimension of knowledge sharing has no significant effect on the development of sustainable Rural Tourism. In the Resource-Based View Theory (RBV Theory), it is stated that resources are a very important factor for organizations to achieve sustainable competitive advantage or superior performance (Shibin et al., 2020). The resource-based view holds that sustainable competitive advantage comes from developing superior capabilities and resources.

RBV Theory focuses on internal organizational resources as a tool to manage processes and gain competitive advantage. Some conclusions state that in order for a potential resource as a source of sustainable competitive advantage, the resource must be valuable, scarce, cannot be replicated perfectly, and cannot be substituted. A resource-based view shows that organizations must develop unique and specific core competencies that enable them to outperform competitors by doing things differently.

In this research the involvement of stakeholders (local communities, government and private sector and NGOs can be categorized as organizational resources that can provide a positive stimulus to the development of sustainable rural tourism and comparative advantage as a category of competitive advantage or superior performance. The research conceptual framework can be described as follows:

\section{STAKEHOLDERS}

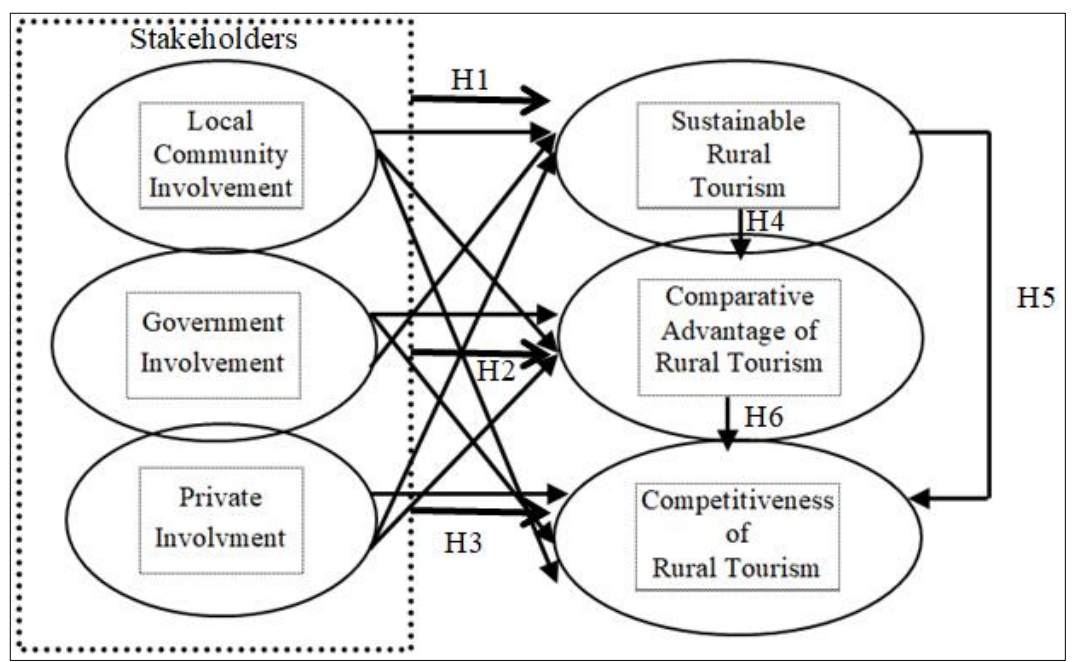

Figure1. Research Conceptual (Source: Adoption of the model: Sook et al., 2014; Xiong et al., 2020) 


\section{Research Hypothesis}

H1: Stakeholders have a positive and significant effect on sustainable rural tourism.

$\mathrm{H}$ 2: Stakeholders have a positive and significant effect on the comparative advantage of rural tourism.

H3: Stakeholders have a positive and significant effect on the competitive advantage of rural tourism.

H4: Rural tourism has a positive and significant effect on the comparative advantage of rural tourism.

H5: Rural tourism has a positive and significant effect on the competitive advantage of rural tourism.

H6: Comparative advantage has a positive and significant effect on the competitive advantage of rural tourism.

\section{Research Methods}

This research was conducted on tourism in Bali Indonesia and is a research with a quantitative approach based on the positivism principle, that is data and theory testing through hypothesis testing. The villages selected as samples are Jatiluwih Village Tabanan Regency, Pengelipuran Village Bangli Regency, and Mas Ubud Village Gianyar Regency. These three villages have become an econ of rural tourism development in Bali. Research respondents numbered 192 including farmers, tourism industry players, village leaders, NGOs, academics and the government. Data were analyzed using the Structural Equation Modeling (SEM) approach using the Smart PLS version 3 software application program (Yudatama et al., 2019)

\section{Measurement Model Test (Outer Model Evaluation) Through \\ Convergent Validity Test}

The measurement model test is based on the factor loading or outer loading coefficient of each indicator on each latent variable. According to Ghozali and Lathan (2012) an indicator is said to be valid if the loading coefficient is above 0.60 and significant at the Alpha level of 0.05 or has a t-statistics value greater than 1.96. Tables 1 and 2 show that the factor loading of all indicators above 0.60 and all shows a significant level of significance, $(\mathrm{PV}=0,000)$.

Table 1. Factor Loading Indicators X1, X2, X3 (Data source: Results of Data Processing)

\begin{tabular}{|c|c|c|c|c|c|c|c|c|}
\hline \multicolumn{3}{|c|}{ Local Community Involvement (X1) } & \multicolumn{3}{|c|}{ Government Involvement (X2) } & \multicolumn{3}{|c|}{ Private and NGO's involvement (X3) } \\
\hline Indicators & Loading Factor & PV & Indicators & Loading Factor & PV & Indicators & Loading Factor & PV \\
\hline $\mathrm{x} .1 .1$ & 0.726 & 0.000 & $\mathrm{x} .2 .1$ & 0.844 & 0.000 & X.3.1 & 0.854 & 0.000 \\
\hline X.1.2 & 0.665 & 0.000 & x.2.2 & 0.876 & 0.000 & $\mathrm{x} .3 .2$ & 0.850 & 0.000 \\
\hline X.1.3 & 0.619 & 0.000 & x.2.3 & 0.897 & 0.000 & $\mathrm{x} .3 .3$ & 0.621 & 0.000 \\
\hline X.1.4 & 0.789 & 0.000 & X.2.4 & 0.813 & 0.000 & & & \\
\hline $\mathrm{x} .1 .5$ & 0.699 & 0.000 & & & & & & \\
\hline
\end{tabular}

Table 2. Factor Loading Indicators X4, X5, X6 (Data source: Results of Data Processing)

\begin{tabular}{|c|c|c|c|c|c|c|c|c|}
\hline \multicolumn{3}{|c|}{ Local Community Involvement (X4) } & \multicolumn{3}{|c|}{ Government Involvement (X5) } & \multicolumn{3}{|c|}{ Private and NGO's involvement (X6) } \\
\hline Indicators & Loading Factor & PV & Indicators & Loading Factor & PV & Indicators & Loading Factor & PV \\
\hline $\mathrm{X} .4 .1$ & 0.753 & 0.000 & X.5.1 & 0.813 & 0.000 & x.6.1 & 0.684 & 0.000 \\
\hline $\mathrm{x} .4 .2$ & 0.788 & 0.000 & $\mathrm{x.5.2}$ & 0.850 & 0.000 & x.6.2 & 0.822 & 0.000 \\
\hline $\mathrm{x} .4 .3$ & 0.629 & 0.000 & x.5.3 & 0.726 & 0.000 & x.6.3 & 0.754 & 0.000 \\
\hline X.4.4 & 0.789 & 0.000 & x.5.4 & 0.636 & 0.000 & x.6.4 & 0.711 & 0.000 \\
\hline X.4.1 & 0.753 & 0.000 & Х.5.1 & 0.813 & 0.000 & х.6.1 & 0.684 & 0.000 \\
\hline
\end{tabular}

Convergent validity can also be seen from the Composite Reliability and Average Variance Extracted (AVE) value. Based on the Composite Reliability value presented in Table 3, it shows that the six constructs have Composite Reliability above 0.6. This means that the predetermined indicators are able to measure each construct well or it can be said that the six measurement models are reliable. The better Convergent Validity value is indicated by the higher correlation between the indicators that make up a construct. In this study, the AVE value of each construct was above 0.5 (Chin, 1998). Therefore there is no convergent validity problem in the model being tested.

Table 3. Construct Reliability and Validity

\begin{tabular}{|c|c|c|c|c|}
\hline Variable & Cronbach's Alpha & rho_A & Composite Reliability & Average Variance Extracted (AVE) \\
\hline X2 & 0.882 & 0.899 & 0.918 & 0.736 \\
\hline X3 & 0.688 & 0.748 & 0.823 & 0.612 \\
\hline X4 & 0.782 & 0.790 & 0.852 & 0.537 \\
\hline X5 & 0.753 & 0.760 & 0.845 & 0.579 \\
\hline X6 & 0.730 & 0.732 & 0.832 & 0.554 \\
\hline
\end{tabular}

Information

$\mathrm{X} 1$ = Community Involvement.

$\mathrm{X} 2=$ Government involvement.

$\mathrm{X} 3$ = Private $/ \mathrm{NGO}$ involvement

X4 = Sustainable Rural Tourism.

X5 = Rural Tourism Comparative Advantage.

X6 = Rural Tourism Competitive Advantage.

\section{Structural Model Test (Inner Model Evaluation)}

The inner model evaluation aims to determine the Goodness of Fit of model with the following methods:

\section{R-Square $\left(R^{2}\right)$}

R-Square $\left(R^{2}\right)$ shows the strengths and weaknesses caused by variations in exogenous variables to endogenous variables. R-Square value $\left(R^{2}\right)$ is the coefficient of determination in endogenous constructs. According to Sarstedt and Cheah (2019), the value of R-Square $\left(R^{2}\right)$ is 0.67 (strong), 0.33 (moderate) and 0.19 (weak). Table 4 shows that the endogenous variable, namely sustainable rural tourism (X4) has R-Square $R^{2}$ at a moderate level (0.463), while the comparative advantage variable of rural tourism (X5) and the competitive advantage of rural 
tourism (X6) has R-Square $\left(R^{2}\right)$ at a strong level, 0.511 and 0.590 , respectively. Thus it can be said that the model formed by the six variables is quite strong. R-Square values $\left(R^{2}\right)$ of each endogenous variable are presented in Table 3 below:

Tabel 4. R-Square (Data source: Results of Data Processing)

\begin{tabular}{|c|c|c|}
\hline Variabele & R Square & R Square Adjusted \\
\hline sustainable rural tourism (X4) & 0.463 & 0.452 \\
\hline comparative advantage variable of rural X5 & 0.511 & 0.498 \\
\hline competitive advantage of rural tourism (X6) & 0.590 & 0.576 \\
\hline
\end{tabular}

Information:
X4 = Sustainable Rural Tourism.
X5 = Rural Tourism Comparative Advantage.
X6 = Rural Tourism Competitive Advantage.

Q-Square (Predictive Relevance)

Q-Square (Predictive Relevance) measures how well the observed value generated by the estimation model and its parameters. Q-Square value $>0$ indicates the model has good predictive relevance. Conversely, if Q-Square $<0$ indicates the model has poor predictive relevance.

The Q-Square (Predictive Relevance) value can be calculated as follows:

$\mathrm{Q}^{2}=1-\left(1-\mathrm{R}^{2} 1\right)\left(1-\mathrm{R}^{2} 2\right)$

$\mathrm{Q}^{2}=1-(1-0.452)(1-0.498)(1-0.576)$

$\mathrm{Q}^{2}=1-(0.548)(0.502)(0.424)$

$\mathrm{Q}^{2}=0.883$

Q-Square calculation produces a value of 0.883 or $88.3 \%$, which means that the model has a very good observation value. That is $88.3 \%$, the relationship between variables can be explained by the model.

\section{GoF (Goodness of Fit) Test}

Goodness of Fit (GoF) Index, used in evaluating structural models and overall measurements that can be calculated with the roots of the AVE average multiplied by the $\mathrm{R}^{2}$ average.

Average $\mathrm{R}^{2}=(0.452+0.498+0.576) 3=0.509$

Average AVE $=(0.736+0.612+0.537+0.579+0.554+0.514)=0.589$

Average AVE x Average $\mathrm{R}^{2}=0.30$

So $\mathrm{GoF}=$ root of $0.30=0.54772$

GoF test criteria are 0.1 (GoF small), 0.25 (moderate GoF), and 0.36 (GoF large), Tenenhaus (2004). So thus the overall evaluation of the research model can be stated well, then it can be continued with the analysis of hypothesis testing

\section{Statistical tests relationships between variables (estimate for path coefficients)}

The results of statistical tests on the relationship of variables (Estimate for Path Coefficients) are path coefficient values that show the influence of exogenous constructs on endogenous constructs carried out with the Bootstrapping procedure on the Smart-PLS 3 application program as Figure 2.

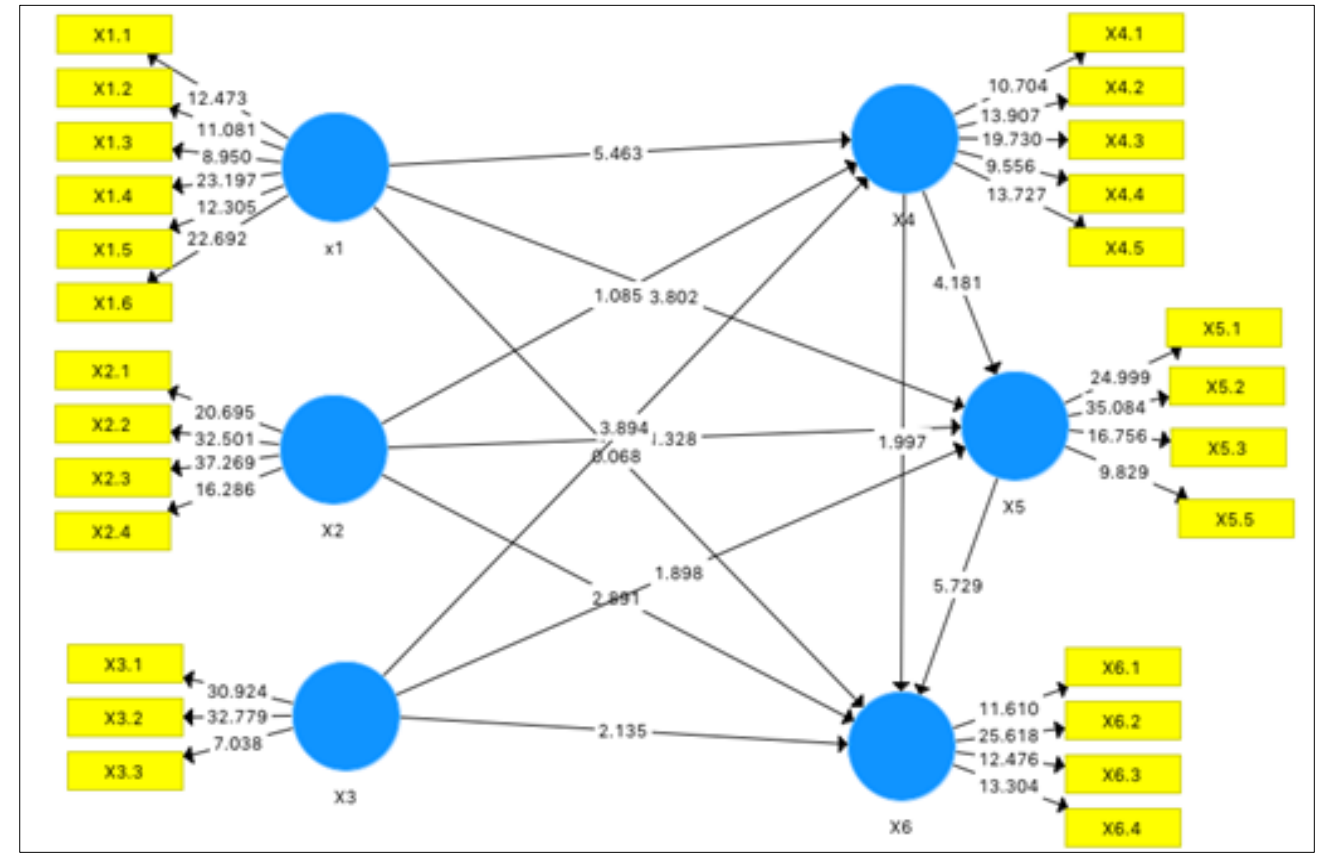

Figure 2. Relationships between variables (Source: Results of Data Processing)

Table 5 shows that out of 12 causality relationships, there were four non-significant causality relationships (hypothesis rejected) at $\alpha 0.05$ with a statistical value $<1.96$. On the other hand there are eight significant causality relationships (hypothesis are accepted) at $\alpha 0.05$ with a statistical value $>1.96$. The relationship that is not significant is between the variables of government involvement with sustainable rural tourism variables; government involvement with the comparative advantage of rural tourism; the involvement of the private sector and NGOs with the comparative advantage of rural tourism and the involvement of the community with the competitive advantage of rural tourism. 
Table 5. Path Coefficients Mean, STDEV, T-Values, P-Values (Data source: Results of Data Processing)

\begin{tabular}{|c|c|c|c|c|c|}
\hline Variable & Original Sample $(\mathrm{O})$ & Sample Mean (M) & Standard Deviation (STDEV) & T Statistics (|O/STDEV $\mid)$ & P Values \\
\hline $\mathrm{X} 2->\mathrm{X} 4$ & -0.084 & -0.075 & 0.078 & 1.085 & 0.279 \\
\hline $\mathrm{X} 2->\mathrm{X} 5$ & 0.087 & 0.089 & 0.066 & 1.328 & 0.185 \\
\hline $\mathrm{X} 2$-> X6 & 0.168 & 0.173 & 0.058 & 2.891 & 0.004 \\
\hline $\mathrm{X} 3$-> X4 & 0.391 & 0.379 & 0.100 & 3.894 & 0.000 \\
\hline $\mathrm{X} 3->\mathrm{X} 5$ & 0.160 & 0.158 & 0.084 & 1.898 & 0.058 \\
\hline X3 -> X6 & 0.187 & 0.186 & 0.088 & 2.135 & $\mathbf{0 . 0 3 3}$ \\
\hline $\mathrm{X} 4$-> X5 & 0.369 & 0.371 & 0.088 & 4.181 & 0.000 \\
\hline $\mathrm{X} 4$-> X6 & 0.167 & 0.167 & 0.083 & 1.997 & 0.046 \\
\hline $\mathrm{X} 5$-> X6 & 0.451 & 0.447 & 0.079 & 5.729 & 0.000 \\
\hline $\mathrm{x} 1->\mathrm{X} 4$ & 0.429 & 0.443 & 0.079 & 5.463 & 0.000 \\
\hline $\mathrm{x} 1$-> X5 & 0.286 & 0.283 & 0.075 & 3.802 & 0.000 \\
\hline x1 -> X6 & 0.005 & 0.010 & 0.073 & 0.068 & 0.946 \\
\hline
\end{tabular}

Information:

$\mathrm{X} 1$ = Community Involvement.

$\mathrm{X} 2$ = Government involvement.

X3 = Private Involvement / L.S.M

X4 = Sustainable Rural Tourism.

X5 = Comparative Advantages of Rural Tourism

X6 = Competitive Advantages of Rural Tourism.

\section{DISCUSSION OF RESEARCH RESULTS}

\section{Local Community Involvement}

The results of research on the relationship of local community involvement variables with the rural sustainable tourism variable, proved to have a strong correlation. This finding is evidenced by the existence of privates and NGOs that support rural tourism especially in carrying out the supervisory function. Likewise, the results of research on the relationship of local community involvement variables with the comparative advantage variable of rural tourism proved to have a strong correlation. This finding is evidenced by the role of the community in participating in supervision to support the preservation of culture and the environment.

But the results of research on the relationship of local community involvement variables with the competitive advantage of rural tourism variable proved to have a weak correlation. This finding is proven because there is no specific activity of the local community related to efforts to develop untouched nature including flora and fauna, and efforts to develop recreational facilities.

\section{Government Involvement}

The results of research on the relationship of government involvement variables with sustainable rural tourism proved to have a weak correlation. This finding is evidenced by the low involvement of the government in managing and conserving the physical environment of the area which is the hallmark of a tourist village and making infrastructure improvements. Likewise the results of research on the relationship of government involvement variables with the comparative advantage variable of rural tourism are shown to have a weak correlation. This finding is evidenced by the low efforts of the government in managing and conserving the physical environment of the area and improving infrastructure. But instead the results of research on the relationship of government involvement variables with the competitive advantage of rural tourism variable proved to have a strong correlation. This finding is evidenced by the government's efforts to support the empowerment of untouched nature including flora and fauna, support for efficient tourist transportation services, and improvement of recreational facilities.

\section{Private and NGOs Involvement}

The results of research on the relationship between the variables of private and NGO involvement with sustainable rural tourism development variables are proven to have a strong correlation. This finding is evidenced by the efforts of private and NGO involvement in conducting entrepreneurship training, skills training in tourism and, developing joint business groups in the community. But the results of research on the relationship between the variables of private and NGO involvement with the comparative advantage variable of rural tourism are shown to have a low correlation. This finding is proven because the involvement of the private sector and NGOs in the development of rural tourism is not integrated with efforts to manage the culture and the unique environment as a village capital appeal.

On the other hand the results of research on the relationship between the variables of private and NGO involvement with the variable of competitive advantage of rural tourism are proven to have a strong correlation. This finding is evidenced by the existence of entrepreneurship training, individual skills training related to integrated tourism businesses with unspoiled nature management efforts including flora and fauna, efficient tourist transportation and recreational facilities.

\section{Relationship of Sustainable Rural Tourism Development with Comparative Advantage}

The results prove that the variable of sustainable rural tourism has a strong correlation with the variable comparative advantage of rural tourism. This finding is evidenced by the efforts to apply the principles of rural tourism development through increasing awareness and love of the community for local culture and through increasing cultural facilities and activities, integrated with efforts to improve the comparative advantage of villages. Efforts to improve comparative advantage relate to efforts to increase employment, improve people's living standards, manage unique cultures and manage the environment as a village capital appeal.

\section{Relationship of Comparative Advantages with Competitive Advantages of Rural Tourism}

The results of the study prove that the comparative advantage of rural tourism has a strong correlation with the competitive advantage of rural tourism. This finding is evidenced by the efforts to manage a unique and diverse culture and to manage the environment as a village capital attraction integrated with efforts to manage untouched nature including flora and fauna, efficient tourist transportation and efforts to improve the quality of recreational facilities

Relationship of Sustainable Rural Tourism Development with Competitive Advantage

The results of the study prove that efforts to develop sustainable rural tourism have a strong correlation with efforts to in crease the 
competitive advantage of rural tourism. This finding is evidenced by an increase in awareness and love of local cult ure and integrated with efforts to manage untouched nature including flora and fauna, availability of efficient tourist transportation and improving the quality of recreational facilities.

\section{Research Implications}

The development of sustainable rural tourism in order to have strong competitiveness must be carried out in an integrated manner by involving the community, government, private sector and non-governmental organizations. Besides that, in implementing rural tourism development, it must focus on implementing the principles of sustainable tourism, comparative advantage and competitive advantage. The results of this study can be used as a basis for developing policies for those who have authority in developing rural tourism.

\section{CONCLUSION}

The involvement of local communities in the development of sustainable rural tourism by managing resources as an element of competitive advantage has an important role. However, community involvement has a low role in fostering the competitive advantage of rural tourism. Government involvement in the development of sustainable rural tourism and encouraging comparative advantage has an insignificant role. While the government's involvement in encouraging the competitive advantage of rural tourism has a significant role.

The involvement of private sector and NGOs in the development of sustainable rural tourism and encouraging competitive advantage has an insignificant role. While the involvement of the private sector and NGOs in encouraging comparative advantage has a significant role.

\section{Recommendation}

The results of this study provide the view that the role of community involvement in increasing the competitive advantage of Rural Tourism must start from efforts to encourage people to understand and implement the principles of sustainable rural tourism development, understanding and implementing natural and cultural resource management as an element of competitive advantage. Government involvement is very important in structuring and conserving the physical environment of the area which is the hallmark of a tourist village and for improving infrastructure including waste and sanitation.

The role of government involvement in the development of rural tourism structurally to improve competitive advantage can be done through increasing understanding and implementation of the principles of sustainable rural tourism and encouraging efforts to empower the unique resources of the village so that it becomes an advantage in competing. Private Involvement and Non-Governmental Organizations have a weak correlation with efforts to manage the comparative advantage of Rural Tourism. Private and Non-Governmental Organizations in enhancing their role through cooperation with the government or related organizations to conduct entrepreneurship training, individual skills training related to businesses in tourism and the development of joint business groups with the community.

\section{Appendix 1}

\section{Community Involvement (X1)}

The community is involved in identifying problems (x1.1)

2 The community is involved in the formulation of objectives (x1.2)

3 Community involved in managing the tourism business ( $\mathrm{x} 1.3)$

4 There are non-governmental organizations involved in supporting rural tourism (x1.4)

5 Communities involved in managing local resources or providing facilities needed in Rural Tourism (x1.5)

6 Have principles so that development strategies do not deviate (x1.6)

Government Involvement (X2)

1 The government provides guidance and funding for local community business activities related to village tourism (x2.1)

2 Arranging and conserving the physical environment of the area that characterizes the tourist village (x2.2)

3 Carry out repairs and procurement of waste and sanitation infrastructure (x2.3)

4 Repair and increase the quality of public spaces (x2.4)

Private Involvement / NGOs (X3)

1 Conducting entrepreneurship training, individual skills training related to business in tourism (x3.1)

2 Development of joint community business groups (x3.2)

3 Providing facilities to get financial assistance (x3.3

Sustainable Rural Tourism (X4)

1 Village tourism can improve the quality of life of communities, improve community identity and have a positive impact (x4.1)

2 Village tourism can increase awareness and love of local culture and improve cultural facilities and activities (x4.2)

3 Village tourism can increase employment and can improve people's living standards, (x4.3)

4 Village tourism does not cause conflict with the interests of the local community, and can protect the environment. (x4.4)

5 Village tourism can preserve the environment $(\mathrm{x} 4.5)$

Comparative Advantage (X5)

1 Having a culture that is relatively unique and more diverse than other village cultures so that it becomes the capital of village attraction (x5.1)

2 Having a different environment compared to other villages so that the village becomes an attraction; (x5.2)

3 Having different types of economic and business and management activities with other tourist villages so that they can provide added value to the village. (X5.3)

4 Culture of population that quickly adjusts to the changes that occur (x5.4)

Competitive Advantage (X6)

1 There are traditional buildings with local cultural architecture (x6.1)

2 There is untouched nature including flora and fauna (x6.2)

3 There is cheap transportation for tourists (x6.3)

4 There are recreational facilities; (x6.4)

\section{REFERENCES}

Afonso, A. (2019). Migrant workers or working women? Comparing labour supply policies in post-war Europe. Journal of Comparative Policy Analysis: Research and Practice, 21(3), 251-269. https://doi.org/10.1080/13876988.2018.1527584

Attack, I. (1999). Four criteria of Development NGO Legitimacy. World Development, 27(5), 855-864. https://doi.org/10.1016/S0305-750X(99)00033-9 
Birkić, D., Čubelić Pilija, I., \& Kljajić Šebrek, J. (2014). The role of local goverment in planning of sustainable tourism of coastal destination. 22nd Biennial International Congress, Tourism \& Hospitality Industry, Trends in Tourism and Hospitality Managament, 16-30.

Clark, J. (1999). Democratizing Development: The Role of Voluntary Organizations. West Hartford, Kumarian Press.

Komppula, R. (2014). The role of individual entrepreneurs in the development of competitiveness for a rural tourism destination - A case study. Tourism Management, 40, 361-371. https://doi:10.1016/j.tourman.2013.07.007

Carvache-Franco, M., Segarra-Oña, M., \& Carrascosa-López, C. (2019). Motivations Analysis In Ecotourism Through An Empirical Application: Segmentation, Characteristics And Motivations Of The Consumer. GeoJournal of Tourism and Geosites, 24(1), 60-73. https://doi.org/10.30892/gtg.24106-343

Croes, R. (2014). Evaluation of tourism competitiveness and its effects on destination management: making a difference in CostaRica? Dialogos, Octubre, 221-232. https://stars.library.ucf.edu/rosenscholar/457

Dogra, R.A., \& Gupta (2012). Barriers to community participation in tourism development: Empirical evidence from a rural destination. South Asian Journal of Tourism and Heritage 5(1), 219-142.

Dogru, T., Suess, C., \& Sirakaya-Turk, E. (2020). Why Do Some Countries Prosper More in Tourism than Others? Global Competitiveness of Tourism Development. Journal of Hospitality \& Tourism Research. https://doi.org/10.1177/1096348020911706

Ertuna, B., \& Kirbas, G. (2012). Local community involvement in rural tourism development: The case of Kastamonu, Turkey. Revistade Turismoy Patrimonio Culture, 10(2), 17-24. https://doi.org/10.25145/j.pasos.2012.10.023

Ezeuduji, I.O. (2015). Brand Positioning for Sub-Saharan Africa's Rural Tourism Development. Journal of Economics and Behavioral Studies, 7(6), 34-41. https://doi.org/10.22610/jebs.v7i6(J).616

Fang, W.T. (2020). Rural Tourism. In Tourism in Emerging Economies (pp. 103-129). Springer, Singapore.

Falak, S., Chiun, L.M. \& Wee, A.Y. (2014). A repositioning strategy for rural tourism in malaysis-community’s perspective, 5th Asia Euro Conference 2014, Procedia Social and Behavioral Sciences, 144, 412-415.

Falciola, J., Jansen, M., \& Rollo, V. (2020). Defining firm competitiveness: A multidimensional framework. World Development, 129. https://doi.org/10.1016/j.worlddev.2019.104857

Ferreira, F., \& Castro, C. (2020). Competitiveness of european tourism: a cluster analysis. In International Conference on Tourism Research (pp. 52-59) Academic Conferences International Limited

Fernández, J.A.S., Azevedo, P.S., Martín, J.M.M., \& Martín, J.A.R. (2020). Determinants of tourism destination competitiveness in the countries most visited by international tourists: Proposal of a synthetic index. Tourism Management Perspectives, 33, 100582. https://doi.org/10.1016/j.tmp.2019.100582

Fong, S.F., \& Lo, M.C. (2015). Community involvement and sustainable rural tourism development: Perspectives from the local communities. European Journal of Tourism Research, 11, 125-146.

Giampiccoli, A., Abdul Muhsin, B., \& Mtapuri, O. (2020). Community-based tourism in the case of the Maldives. GeoJournal of Tourism \& Geosites, 29(2), 428-439. https://doi.org/10.30892/gtg.29204-479

Ghozali, I. \& Latan, H. (2012). Partial Least Square: Konsep, Teknik dan Aplikasi SmartPLS 2.0 M3. Semarang: Badan Penerbit Universitas Diponegoro.

Jaafar, M., Md Noor, S., Mohamad, D., Jalali, A., \& Hashim, J.B. (2020). Motivational factors impacting rural community participation in community-based tourism enterprise in Lenggong Valley, Malaysia. Asia Pacific Journal of Tourism Research, 25(7), 697-710. https://doi.org/10.1080/10941665.2020.1769696

Kastenholz, E., Carneiro, M.J., Marques, C.P., \& Lima, J. (2012). Understandig and managing Management Perspectives, 4, 207-214. https://doi.org/ 10.1016/j.tmp.2012.08.009

Komppula, R. (2014). The role of individual entrepreneurs in the development of competitiveness for a rural tourism destination - A case study. Tourism Management, 40, 361-371. https://doi.org/10.1016/j.tourman.2013.07.007

Kubickova, M. (2016). The Role of Government in Tourism: Linking Competitiveness, Freedom, and Developing Economies. Czech Journal of Tourism, 5(2), 73-92. https://doi.org/10.1515/cjot-2016-00005. https://doi.org/10.1515/cjot-2016-0005

Lee, T.H., \& Jan, F.H. (2019). Can community-based tourism contribute to sustainable development? Evidence from residents' perceptions of the sustainability. Tourism Management, 70, 368-380. https://doi.org/10.1016/j.tourman.2018.09.003

Lee, T.H. (2013). Influence analysis of community resident support for sustainable tourism development. Tourism Management, 34, 37-46 https://doi.org/10.1016/j.tourman.2012.03.007

Liu, J., \& Xie, J. (2020). Environmental regulation, technological innovation, and export competitiveness: An empirical study based on China's manufacturing industry. International Journal of Environmental Research and Public Health, 17(4), 1427. https://doi.org/10.3390/ijerph17041427

Lo, M.C., Mohamad, A.A., Songan, P., Yeo, A.W. (2012). Positioning rural tourism: perspectives from the local communities. International Journal of Trade, Economics and Finance, 3(1), 59-65.

Ma, X.L., Dai, M.L., \& Fan, D.X. (2020). Cooperation or confrontation? Exploring stakeholder relationships in rural tourism land expropriation. Journal of Sustainable Tourism, 1-19. https://doi.org/10.1080/09669582.2020.1762622

Othman, B., Khatab, J.J., Esmaeel, E.S., Mustafa, H.A., \& Sadq, Z.M. (2020). The Influence of Total Quality Management on Competitive Advantage towards Bank Organizations: Evidence from Erbil/Iraq. International Journal of Psychosocial Rehabilitation, 24(5), 3427-3439. https://doi.org/10.37200/I JPR/V24I5/PR202053

Prevolšek, B., Maksimović, A., Puška, A., Pažek, K., Žibert, M., \& Rozman, Č. (2020). Sustainable development of ethno-villages in bosnia and herzegovina a multi criteria assessment. Sustainability, 12(4), 1399. https://doi.org/10.3390/su12041399

Porter, M. (1980). The Competitive Strategy. Techniques for Analysing Strategy Industries and competitors. New York The free Press.

Porter, M. (1990). The Competitive Advantage of Nations. London: The Macmillan Press.

Sandri, O., Hayes, J., \& Holdsworth, S. (2020). Regulating urban development around major accident hazard pipelines: a systems comparison of governance frameworks in Australia and the UK. Environment systems and decisions, 40(3), 385-402.

Sarstedt, M., \& Cheah, J.H. (2019). Partial least squares structural equation modeling using SmartPLS: a software review. Journal of Marketing Analytics, 7(3), 196-202.

Shibin, K.T., Dubey, R., Gunasekaran, A., Hazen, B., Roubaud, D., Gupta, S., \& Foropon, C. (2020). Examining sustainable supply chain management of SMEs using resource based view and institutional theory. Annals of Operations Research, 290(1), 301-326.

Sook, F., May, L., Songan, P., \& Nair, V. (2014). The impact of local communities involvement and relationship quality on sustainable tourism in rural. Procedia-social and behavioral Sciences.

Ursache, M. (2015). Niche Tourism Markets-Means of Enhancing Sustainable Economic Development in Eu's Eastern Periphery. CES Working Papers, 7(2A), 648-661.

Wardana, I.M, Utama, I.W.M., \& Astawa, I.P. (2018). Model Of Local Population Perception In Supporting Coastal Tourism Development And Planning In Bali. Geojournal Of Tourism And Geosites, 23(3), 873-880. https://doi.org/10.30892/gtg.23321-335

Wardana, I., Sukaatmadja, I., Ekawati, N., Yasa, N., Astawa, I., \& Setini, M. (2020). Policy models for improving ecotourism performance to build quality tourism experience and sustainable tourism. Management Science Letters, 11(2), 595-608.

Xiong, Y., Zhang, Y., \& Lee, T.J. (2020). The rural creative class: An analysis of in-migration tourism entrepreneurship. International Journal of Tourism Research, 22(1), 42-53

Yasa, N.N.K., Yasa, N.N.K., Giantari, I.G.A.K., \& Giantari, I.G.A.K. (2020). The role of competitive advantage in mediating the effect of promotional strategy on marketing performance. Management Science Letters, 10(12), 2845-2848.

Yudatama, U., Hidayanto, A.N., Nazief, B.A., \& Phusavat, K. (2019). Data to model the effect of awareness on the success of IT Governance implementation: A partial least squares structural equation modeling approach (PLS-SEM). Data in brief, 25, 104333. https://doi.org/10.1016/j.dib.2019.104333 